\title{
MODULAR SYSTEM PENDIDIKAN AGAMA ISLAM UNTUK MENGEMBANGKAN PENDIDIKAN KARAKTER PESERTA DIDIK DI SEKOLAH
}

\author{
Oleh: \\ RAHMAT *
}

\section{Abstrak}

Dewasa ini guru pendidikan agama Islam (PAI) di sekolah-sekolah mengeluh sebab kesulitan dalam menyampaikan pelajaran dan kesulitan dalam menginternalisasikan karakter pada peserta didiknya. Hal ini cukup beralasan dikarenakan seorang pengajar/guru masih kurang mumpuni ketika memilih, metode, menggunakan teknik, dan bahkan tidak mengetahui kebutuhan para peserta didik dan bisa jadi juga ketidak pahaman pengajar terhadap tingkat kecepatan belajar mereka. Akibatnya, banyak peserta didik yang tidak menyukai suatu materi ajar tertentu bahkan tidak menyukai pengajarnya jika demikian, lantas bagaimana seorang pengajar akan mendidikkan kognitif, psikomotorik bahkan menginternalisasikan afektif. Sejatinya hal semacam ini tidak akan terjadi jika sistem pembelajarannya diperbaiki, karena belajar adalah sebuah proses maka pengajar tidak pernah tahu kapan peserta didik mengalami proses belajar tersebut. Sehingga, apabila seorang pengajar membangun sebuah sistem pembelajaran maka mengajar itu akan terasa lebih mudah dan peserta didikpun akan dapat menemukan minat dan motivasi belajarnya. Dalam artikel ini, penulis coba menyajikan solusi untuk membangun sebuah sistem dalam pembelajaran PAI, dengan menggunakan modular system. Modular sistem merupakan sebuah sistem guna memfasilitasi kebutuhan belajar tiap individu peserta didik di sekolah. Dengan sistem ini diharapkan pembelajaran lebih humanis dan menyenangkan.

* IKHAC Pacet-Mojokerto, Mahasiswa Program Doktoral UIN Maliki Malang Prodi PAI-BSI Angkatan 2015, e-mail : rahmatfatahillah@gmail.com 
Kata kunci: Modular System, PAI, Pendidikan Karakter

\section{Pendahuluan}

Apabila kita amati pada sekolah-sekolah tradisional (sekolah biasa) ternyata amat banyak waktu yang digunakan oleh para siswa untuk mendengarkan dan mencatat. Sedangkan proses belajar itu sendiri berjalan dengan kekurangan waktu. Bahkan banyak kegiatan belajar yang sebenarnya terjadi di luar pengawasan guru. Keadaan demikian tidak memungkinkan guru mengawasi dan membantu murid dalam mencari kebiasaan yang baik dalam belajar, sedang sementara itu waktu sekolah kurang dimanfaatkan untuk keaktifan belajar tetapi hanya untuk mendengarkan dan mencatat keterangan-keterangan pelajaran yang diberikan oleh guru.

Di samping itu yang perlu diperbaiki dari Pengajaran Sistem Tradisional yang sangat klasikal ialah anggapan bahwa semua anak mempunyai kemampuan dan kecepatan belajar yang sama sehingga dalam waktu yang sama semua siswa dianggap akan dapat menyelesaikan volume pelajaran yang sama. Anggapan ini sebenarnya keliru; pada kenyataannya di dalam kelas selalu ada anak yang cepat; anak yang rata-rata dan anak yang lambat dalam mengikuti pelajaran.

Keadaan seperti yang terurai secara umum di atas kurang memberikan harapan bagi berlangsungnya suatu proses belajar mengajar yang efisien dan efektif. Modul sebagai sistem penyampaian dalam proses belajar mengajar telah dijadikan tumpuan harapan untuk mampu mengubah keadaan tersebut menjadi situasi belajar mengajar yang merangsang, yang lebih mengaktifkan murid untuk membaca dan belajar memecahkan masalah sendiri di bawah pengawasan dan bimbingan guru yang selalu siap menolong murid yang mempunyai kesulitan. ${ }^{1}$

Dari uraian di atas, penulis merumuskan masalah yakni, pertama, bagaimana Perkembangan Instruksional Modular System di di Sekolah Indonesia? Kedua, bagaimanakah Peranan

${ }^{1}$ B. Suryosubroto, Sistem Pengajaran dengan Modul, (Yogyakarta: PT. Bina Aksara, 1983), hlm. 11-13. Bandingkan dengan, S. Nasution, Berbagai Pendekatan dalam Proses Belajarn \& Mengajar, (Jakarta: PT Bumi Aksara, 2006), cet. X, hlm. 204-221. 
Modular System dalam Pembelajaran Pendidikan Agama Islam (PAI) di Sekolah? Dan ketiga, bagaimanakah implikasi Modular System Pendidikan Agama Islam dalam mengembangkan pendidikan karakter peserta didik di sekolah?

\section{Pembahasan}

\section{Pengembangan Instruksional Modular System di Sekolah Indonesia}

Dalam beberapa dekade terakhir, istilah pengajaran telah banyak ditinggalkan dan seakan tenggelam, digantikan oleh istilah instruksional (pembelajaran). Yang dimaksud dengan kegiatan instruksional atau pembelajaran adalah " $a$ set of events which affect learners in such a way that learning is facilitated" kegiatan instruksional atau pembelajaran adalah suatu rangkaian peristiwa yang memngaruhi peserrta didik atau pembelajar sedemikian rupa sehingga perubahan perilaku yang disebut hasil belajar terfasilitasi. Pembelajaran mengandung makna bahwa serangkaian kegiatan belajar itu dirancang lebih dahulu agar terarah pada tercapainya perubahan perilaku yang diharapkan. Rangkaian kegiatan itu dilaksanakan peserta didik dengan atau tanpa fasilitas pengajar (learner-centered or learner oriented).

Pengembangan instruksional adalah terminologi yang berkembang sejak kurang lebih lima puluh tahun yang lalu. Penerapan di Indonesia mulai populer dengan penggunaan Prosedur Pengembangan Sistem Instruksional yang disingkat PPSI pada permulaan 1970, khususnya dalam mengiringi munculnya Kurikulum 1975 yang berlaku untuk tingkat Sekolah Dasar dan Sekolah Menengah dan Perguruan Tinggi dan lembaga Diklat. ${ }^{3}$

Akan tetapi, kondisi belajar, gaya belajar (kecepatan belajar) peserta didik pasti berbeda. ${ }^{4}$ Sehingga para guru kesulitan untuk memfasilitasi perbedaan tiap-tiap individu

${ }^{2}$ R. M. Gagne \& L. J. Briggs, Principle of Instructional Design, 1nd ed (New York: CBS College Publishing, 1979), hlm. 3.

${ }^{3}$ M. Atwi Suparman, Desain Instruksional Modern, cet-4, (Jakarta: Erlangga, 2014), 102.

4 A. Tresna Sastrawijaya, Pengembangan Program Pengajaran, (Jakarta: PT Rineka Cipta, 1991), hlm. 40. 
tersebut. Guna mengatasi kesulitan tersebut, para ahli pendidikan telah memikirkan jalan keluar, di antaranya melalui pembelajaran dengan modul. ${ }^{5}$ Modul adalah suatu paket pengajaran yang memuat satu unit konsep bahan pelajaran. Pembelajaran modul ini merupakan usaha penyelenggaraan pembelajaran individual yang memungkinkan siswa menguasai satu unit bahan pelajaran sebelum dia beralih kepada unit berikutnya. Modul itu disajikan dalam bentuk yang bersifat selftinstructional dimana setiap siswa dapat menentukan kecepatan dan intensitas belajarnya sendiri.

Melihat sejarahnya, pada tahap pertama (ekspresimentasi) sistem pengajaran/pembelajaran baru ini diterapkan pada sekolah-sekolah yang dipergunakan sebagai Proyek Perintis Sekolah Pembangunan (PPSP). Seperti kita ketahui Departemen Pendidikan \& Kebudayaan telah menunjuk diselenggarakannya PPSP itu pada 8 (delapan) tempat yakni di Padang, Jakarta, Bandung, Semarang, Yogyakarta, Surabaya, Malang dan Ujungpandang. Masing-masing PPSP ditangani oleh IKIP Negeri setempat.

Sejak tahun 1975 sistem pembelajaran/pengajaran dengan modul ini dilaksanakan pada PPSP tersebut. Untuk kelas I, IV, VI, dan IX (kelas IX pada PPSP setingkat dengan kelas I SMA). Pada waktu itu belum seluruh bidang studi diajarkan dengan sistem modul, melainkan baru untuk bidang studi IPA, IPS, Matematika, dan Bahasa (Bahasa Indonesia dan Bahasa Inggris). ${ }^{6}$

Modular system ini dianggap sukar diterapkan untuk para siswa sekolah dasar dan lebih cocok diterampakan pada siswa SMP ke atas, dengan alasan mereka (para siswa SD) masih kesulitan dalam memahami bacaan atau miskin bacaan, dan dirasa kesukaran dalam memahami perintah atau petunjuk

${ }^{5}$ Vebriarto, Pengantar Pengajaran Modul, (Yogyakarta: Pendidikan Paramita, 1981), hlm. 20. Baca juga, Heni Mularsih, Strategi Pembelajaran, Tipe Kepribadian dan Hasil Belajar Bahasa Indonesia Pada Siswa Sekolah Menengah Pertama, Jurnal, Makara, Sosial Humaniora, Vol. 14, No. 1, Juli 2010: 65-74.

${ }^{6}$ B. Suryosubroto, Sistem Pengajaran dengan Modul.......hlm. 9. 
modul. $^{7}$ Namun, pada perkembangannya, hasil penelusuran penulis, modular system telah mulai diujicobakan dan berlangsung hingga sekarang di sekolah dasar secara terbatas di sekolah dasar laboratorium milik IKIP yang tersebar di 8 daerah di Indonesia, seperti di Jawa Timur terdapat 4 sekolah bawah naungan IKIP yang menerapakan individual instruction dengan modular system di sekolah dasarnya yakni 2 SD di IKIP Malang sekarang dikenal dengan Universitas Negeri Malang (UM) yang terletak di J1. Borgor 19 dan di Blitar di Jl. Ir. Soekarno 1, dan 2 SD IKIP Surabaya (Universitas Negeri Surabaya/UNESA) di Jl. Ketindan dan Lidah Wetan. ${ }^{8}$

\section{Peranan Modular Sistem dalam Pembelajaran Pendidikan Agama Islam (PAI) di Sekolah}

Sebagaimana telah dikemukakan di muka, pembelajaran modular system (sistem modul) pada dasarnya adalah sistem pembelajaran melalui media yang disebut modul. Modul adalah suatu paket pengajaran yang berkenaan dengan suatu unit terkecil bertahap dari mata pelajaran tertentu. Dikatakan bertahap, sebab modul itu dipelajari secara individual dari satu unit ke unit lainnya. Salin itu, pengajara modular menggunakan multimedia. Dalam situasi itu, siswa mengajar dirinya sendiri. Para peserta didik melakukan kontrol sendiri terhadap intensitas belajarnya. ${ }^{9}$

Modular system merupakan perwujudan sebuah inovasi untuk membantu para guru ketika mengalami kesulitan dalam melayani minat, kebutuhan, irama belajar masing-masing

7 Baca, Nana Sudjana \& Ahmad Rivai, Teknologi Pengajaran, (Bandung, Sinar Baru, 1989), hlm. 119.

${ }^{8}$ Dan yang menggunakan modular system ini di tingkat Perguruan Tinggi (PT) seperti Universitas Terbuka (UT) adapun kebanyakan kampus di Indonesia menggunakan istilah lain yakni "Sistem Kredit Semester (SKS)" namun sejatinya tujuannya sama, yaitu sebagai program yang penyajiannya bervariasi dan luwes, serta memungkinkan penyaluran bakat, minat dan kemampuan mahasiswa. Baca, Slameto, Proses Belajar Mengajar dalam Sistem Kredit Semester 'SKS', (Jakarta: Bumi Aksara, 1991), hlm. 254-310.

${ }^{9}$ Oemar Hamalik, Sistem Pembelajaran Jarak Jauh dan Pembinaan Ketenagaan, (Bandung: Trigenda Karya, 1994), hlm. 145. 
siswanya di sekolah (kelas) terutama guru pendidikan agama Islam (PAI).

Adapun komponen-komponen modul adalah, a) Pedoman guru, berisi petunjuk-petunjuk agar guru mengajar secara efisien serta memberikan penjelasan tentang jenis-jenis kegiatan yang harus dilakukan oleh siswa, waktu untuk menyelesainakn modul, alat-alat pelajaran yang harus dipergunakan, dan petunjuk-petunjuk evaluasinya, b) Lembar kegiatan siswa, memuat pelajaran yang harus dikuasai oleh siswa. Susunan materi sesuai dengan tujuan instruksionla yang akan dicapai, disusun langkah demi langkah sehingga mempermudah siswa belajar. Dalam lembaran kegiatan tercantum kegiatan-kegiatan yang harus dilakukan oleh siswa, misalnya melakukan percobaan, membaca kamus, 3) Lembar kerja, menyertai lembaran kegiatan siswa yang dipakai untuk menjawab atau mengerjakan soal-soal tugas atau masalah-masalah yang harus dipecahkan, 4) Kunci lembar kerja, berfungsi untuk mengevaluasi atau mengoreksi sendiri hasil pekerjaan siswa. Bila terdapat kekeliruan dalam pekerjaannya, siswa bisa meninjau kembali pekerjaannya, 5) Lembar tes, merupakan alat evaluasi untuk mengukur keberhasilan tujuan yang telah dirumuskan dalam modul. Lembaran tes berisi soal-soal guna menilai keberhasilan siswa dalam mempelajari bahan yang disajikan dalam modul, 6) Kunci lembar tes, merupakan alat koreksi terhadap penilaian yang dilaksanakan oleh para siswa sendiri.

Sedangkan evaluasi dalam pembelajaran dengan modul, lebih mementingkan kualitas dalam penguasaan bahan pelajaran. Paling tidak $80 \%$ dari tujuan harus dikuasai untuk kemudian baru dapat melanjutkan atau pindah ke modul berikutnya. Oleh sebab itu, perlu tes formatif pada setiap modul untuk mengetahui tercapai-tidaknya kriteria $80 \%$ tersebut. Untuk akhir tahun ajaran perlu tes sumatif yang akan mengukur tingkat penguasaan siswa terhadap seluruh modul yang dipelajari.

Sehingga dengan pembelajaran PAI dengan sistem modul ini sangat lengkap dengan komponen-komponen sebagaimana di atas serta di antara teori yang melandasi sistem modul ini seperti mastery learning (belajar tuntas) dan maju berkelanjutan. Dengan sistem modul ini peserta didik diasumsikan dapat 
menguasai materi dengan tuntas karena sistem modul adalah sebuah sarana untuk belajar secara individual, bagi peserta didik yang memiliki kecepatan belajar berbeda maka akan sangat terfasilitasi. Maju berkelanjutan, artinya peserta didik yang telah menguasai tiap penggalan dalam modul dan menuntaskan pembelajarannya akan dapat mengerjakan modul berikutnya sehingga si pesert didik tersebut secara alamiah mengikuti akselerasi walaupun sebenarnya tidak ada kontrak mengikuti program akselerasi.

Peserta didik boleh mengambil pembelajaran melampaui teman-temanya tanpa harus menunggu teman-temannya yang tingkat belajarnya sedang ataupun lamban (bagi peserta didik yang berkesulitan belajar/berkebutuhan khusus). ${ }^{10}$ Namun apabila nilai penggalan dalam modul dan atau evaluasi tiap penggalan modul belum mencapai kriteria ketuntasan minimum (KKM) suatu mata pelajaran maka ia tidak diperbolehkan mengambil atau mengerjakan penggalan modul atau evaluasi berikutnya.

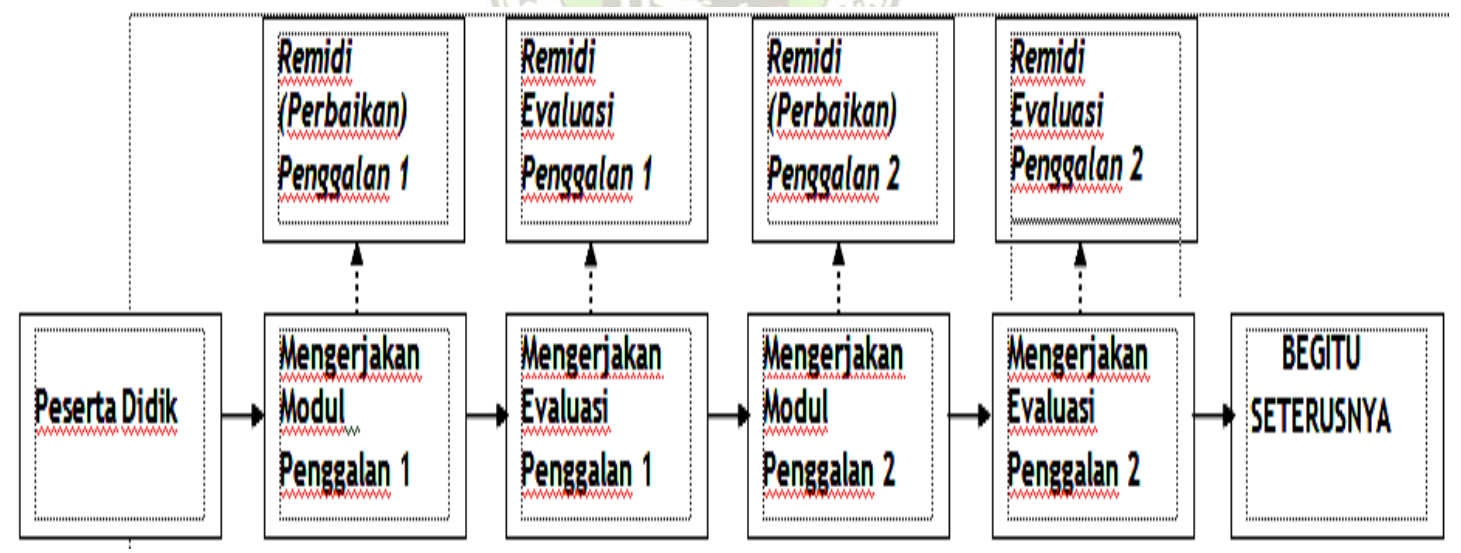

Gambar 1. Modular System, mastery learning dan maju berkelanjutan

si A telah mengerjakan penggalan 1 dan telah mencapai KKM maka ia boleh mengerjakan evaluasi penggalan 1 namun jika nilainya tidak mencapai KKM dilakukanlah remedial baru

10 Baca Aspek psikologis dari kesulitan belajar oleh: Mulyono Abdurrahman, Pendidikan Bagi Anak Berkesulitan Belajar, (Jakarta: PT Rineka Cipta, 2003), hlm. 83-93. 
kemudian boleh evaluasi, selanjutnya, apabila si A telah mengerjakan penggalan 1 berikut evaluasi penggalan 1 maka ia berhak mengambil/mengerjakan modul 2 dan evaluasi penggalan 2 apabila nilai penggalan 2 ataupun nilai evaluasi penggaln 2 tidak memnuhi KKM maka dilakukan remedial dan manakala telah mencapai standar KKM boleh melanjutkan ke modul berikutnya dan begitu selanjutnya. Kalau dalam satu modul itu ada 10 penggalan tentu ada 10 evaluasi, ini artinya tiap satu penggalan ada evaluasinya. Apabila modular system di berlakukan dalam konteks sekolah dasar (SD) kelas 4. Asumsinya jikalau kelas 4 SD ada 5-6 mata pelajaran, berarti ada 5-6 modul, dan sibelajar mampu melahap semua penggalan dari 5-6 modul tersebut otomatis diperkenankan mengambil modul kelas berikutnya yakni kelas 5 . Tidak berlebihan kalau penulis kemudian mengasumsikan bahwa pembelajaran PAI dengan modular system sangat efektif dan efisien. Sangat membantu gaya belajar, kebutuhan, dan motivasi tiap individu peserta didik serta dapat menghemat waktu dan biaya. ${ }^{11}$ Menghemat waktu karena modular system dapat memfasilitasi kecepatan belajar peserta didik. Dan dapat menghemat biaya disebabkan dengan kecepatan belajar peserta didik tersebut sehingga biaya pun dapat diminimalkan, rasionalnya kalau sekolah dasar (SD) harus ditempuh selama 6 tahun (3 tahun untuk SMP dan SMA), maka peserta didik dapat menyelesaikannya tidak sampai 6 tahun, bisa 5 hingga 5 setengah tahun (2 hingga 2 tahun setengah untuk SMP dan SMA).

Lalu apabila modular system ini hanya dipraktekkan dalam pelajaran PAI saja dalam sebuah sekolah, inipun akan menguntungkan si peserta didik dan pengajarnya. Manfaat yang didapatkan oleh peserta didik yakni ia dapat menguasai semua materi modul PAI hingga modul kelas 6, dan manfaat bagi

11 Baca konsep belajar Humanisme (filosofi belajar yang sangat memerhatikan keunikan-keunikan yang dimiliki oleh peserta didik/gaya belajar yang dimiliki peserta didik), dalam Baharuddin \& Esa Nur Wahyuni, Teori Belajar dan Pembelajaran, (Jogjakarta: Ar-Ruzz Media, 2007), hlm. 143. Lihat, Ratna Wilis Dahar, Teori-teori Belajar \& Pembelajaran, (Jakarta: Erlangga, 2011), hlm. 17-27. 
pengajar/guru ia akan lebih focus membimbing peserta didik yang gaya belajarnya terkesan lamban (peserta didik yang berkesulitan belajar/berkebutuhan khusus) serta memberikan pengayaan $^{12}$ dan studi mendalam bagi peserta didik yang telah menyelesaikan seluruh modul PAI yang berakhir pada kelas 6 tersebut.

\section{Implikasi Modular System Pendidikan Agama Islam dalam Mengembangkan Pendidikan Karakter Peserta Didik di Sekolah}

Pendidikan Agama Islam sebagai pondasi pendidikan karakter (akhlak). Akan tetapi timbul kecurigaan penulis, kalau pembelajar PAI di Indonesia ini bertujuan membentuk peserta didik yang berilmu dan kurang bertujuan pada membentuk peserta didik yang ahli ibadah. Ungkapan ini cukup beralasan karena memperhatikan muatan materi dan praktek pembelajaran yang lebih menekankan pada intelektual dan kompetensi saja (mementingkan latihan soal dan praktek) dan kurang sekali menyentuh keranah afeksinya (sikap). Hal senada disampaikan oleh Amin Abdullah dalam Muhaimin ${ }^{13}$ menyoroti kegiatan pembelajaran pendidikan agama Islam (PAI ) di sekolah dan menyimpulkan:

1. Pendidikan agama lebih banyak berkonsentrasi pada persoalan-persoalan teoritis keagamaan yang bersifat kognitif serta amalan-amalan ibadah praktis.

2. Pendidikan agama kurang concern terhadap persoalan bagaimana mengubah pengetahuan agama yang kognitif menjadi makna dan nilai yang perlu diinternalisasikan dalam diri siswa lewat berbagai cara, media dan forum.

3. Isu kenakalan remaja, perkelahian diantara para pelajar, tindak kekerasan, premanisme, white color crime, mengkonsumsi minuman keras dan sebagainya, walaupun

12 Baca kegiatan pengayaan, Sri Anita W Dkk, Strategi Pembelajaran di SD (Tangerang Selatan: Universitas Terbuka, 2014) Cet ke20, Modul 9 Kegiatan Remedial dan Kegiatan Pengayaan, 9.31.

13 Muhaimin.Paradigma Pendidikan Islam Upaya Mengefektifkan Pendidikan Agama Islam Di Sekolah.(Bandung: Remaja Rosda Karya: 2001) hlm. 90. 
tidak secara langsung ada keterkaitan dengan pola metodologi pendidikan agama yang selama ini berjalan secara konvensional.

4. Metodologi pendidikan agama yang tidak kunjung berubah antara pra dan post era modernitas.

5. Pendidikan agama lebih menitikberatkan pada aspek korespondensi tekstual, yang lebih menekankan hafalan teks-teks keagamaan yang sudah ada.

6. Sistem evaluasi, bentuk-bentuk soal ujian agama menunjukkan prioritas utama kognitif dan jarang pertanyaan tersebut mempunyai bobot muatan nilai dan makna spiritual keagamaan yang fungsional dalam kehidupan sehari-hari.

Karena konsentrasi guru di sekolah terlalu terfokus pada penyampaian pengetahuan, sering kali guru bertindak keras terhadap anak yang tidak bisa mengikuti pelajaran dengan baik dan tidak jarang guru mudah memberi label "anak bodoh, anak anak" kepada peserta didik. Catatan Amin Abdullah di atas, bisa jadi merupakan salah satu alasan munculnya Kurikulum 2013 (K13). Walaupun kemunculan kurikulum ini banyak yang pro dan kontra, namun K13 adalah perwujudan dari keseriusan pemerintah dalam memperbaiki karakter (akhlak) bangsa. Dan benar, seyogyanya kita mendukung upaya pemerintah tersebut dengan mempelajari dan menerapkan K13 itu di sekolah. Akan tetapi, apakah K13 ini benar-benar relevan untuk menumbuhkembangkan karakter pada peserta didik? Bukankah pendidikan agama secara esential Islam adalah agama pengetahuan? Islam memandang pengetahuan sebagai cara yang utama bagi penyelamatan jiwa dan pencapaian kebahagiaan serta kesejahteraan manusia dalam kehidupan kini dan nanti. Islam tidak hanya membahas apa yang wajib dan yang dilarang untuk dilakukan manusia, tetapi juga membahas apa yang perlu diketahui manusia.

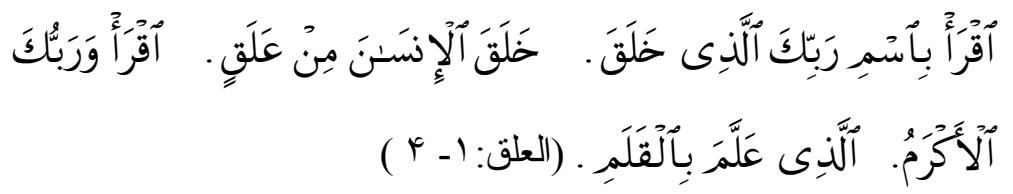


Terjemahnya : Bacalah dengan (menyebut) nama Tuhanmu yang Menciptakan, Dia telah menciptakan manusia dari segumpal darah. Bacalah, dan Tuhanmulah yang Maha pemurah,yang mengajar (manusia) dengan perantaran kalam.

Ayat di atas, mengajak manusia untuk berpikir secara rintegrasi, dan itu hanya bisa dilakukan dengan menyebut nama Allah Swt, membaca itu mengkomposisi ulang realita lalu memaknainya atau berkontempolasi dan menginterasi. Manusia diciptakan dari segumpal darah yang rendah, tapi Rabb menyebut manusia dalam istilah "insan", makhluk pembelajar, bukan basyar (makhluk biologis) atau nas (makhluk yang mengikuti dorongan psikologis). Manusia itu adalah makhluk pembelajar, pembelajar itu misi insan.

Pertanyaannya, apakah benar modular system cukup membangun pendidikan karakter peserta didik? Dari uraian di atas, dipahami bahwa pembelajaran PAI dengan modular system membantu peserta didik dalam penguasaan materi dan diharapkan cakap dalam mempraktekkan pengetahuannya itu dalam ritual ibadah. Sebagai implikasi pembelajaran PAI dengan modular system bisa mengembangkan pendidikan karakter peserta didik bisa dianalisis dari tujuan modular system. Modular system yang berciri khas pembelajaran individual, mastery learning dan maju berkelanjutan penulis memiprediksikan akan mengembangkan karakter peserta didik, 1) Gemar memaca, 2) Rasa ingin tahu, 3) Jujur, 4) Disiplin, 5) Kerja keras, 6) Kreatif, 7) Mandiri, 8) Demokrasi, 9) Komonikatif, 10) Tanggungjawab, 11) Strategi belajar ${ }^{15}$ Tetapi, apakah pembelajaran PAI dengan modular system ini berimplikasi membangun karakter ini saja? Bagaimana dengan karakter religius?

\footnotetext{
${ }^{14}$ Al-Qur'an in word, Q.S. Al-Alaq: 1-4. Maksudnya: Allah mengajar manusia dengan perantaraan baca tulis.

${ }^{15}$ Baca 18 Karakter dan berikut penjelasannya yang bersumber dari agama, Pancasila, budaya, dan tujuan pendidikan nasioanl dalam Kementrian Pendidikan Nasional Badan Penelitian Dan Pengembangan Pusat Kurikulum, Pedoman Pelaksanaan Pendidikan Karakter (Jakarta: Balitbang Diknas, 2010), hlm 9-10.
} 
Sebenarnya pembelajaran PAI itu sendiri adalah karakter (akhlak) religius itu sendiri. Namun, ternyata berapa banyak individu yang tingkat pemahaman agamanya tinggi, dan tingkat praktek ibadahya banyak ternyata sikap/karakter religius masih kurang. Sikap religius dapat ditunjukkan dengan seberapa peduli si peserta didik dengan lingkungannya? Seberapa toleran ia dengan teman yang tak seakidah dengannya? Sedalam apa kecintaannya terhadap Negara? Setulus apa ia beribadah kepada Tuhannya?

Seringkali kita mendapati orang-orang yang tingkat pemahaman dan tingkat ibadahnya tinggi tapi sikap-sikap yang penulis pertanyakan di atas malah tidak tercermin pada dirinya. Berarti, bukan jaminan peserta didik yang nilai modul, evaluasi dan praktek agamanya tinggi lantas sikap/karakter religius baik. Maka dari itu dirasa perlu mengejahwantahkan karakter atau melakukan pembiasaan (biasa disebut budaya religius). Sebagus apapun kurikulum, metode/strategi dan sistem pembelajaran yang dimiliki sebuah sekolah apabila tidak diterapkan budaya religus maka akan kesulitan dalam membangun karakter religius peserta didik.

Budaya religius adalah sekumpulan nilai-nilai agama yang melandasi prilaku, tradisi kebiasaan keseharian dan symbolsimbol yang dipraktikkan oleh kepala sekolah, guru, petugas administrasi, peserta didik, dan masyarakat sekolah. ${ }^{16}$

Apakah tidak terlalu sulit bagi seorang pengajar (guru) untuk menggerakkan warga sekolah agar membangun karakter religius dengan menerapakan budaya religius di sekolah? Kemungkinan susah dilakukan. Menurut penulis cara mengatasinya, seyogyanya guru PAI yang menggunakan modular system dalam pembelajaran PAI di sekolah, maka tetap dapat membangun karakter religius dengan jalan membuat modulnya sendiri. Dengan membuat modulnya sendiri, maka si pengajar akan tahu kebutuhan peserta didiknya, dan ia berkuasa

16 Baca Muhaimin, Pemikiran Pendidikan Islam, (Bandung: Trigenda Karya, 1993), hlm. 110. Bandigkan dengan tulisan Mohamad Iwan Fitriani, Pola Pengembangan Program Suasana Religius Melalui Aktualisasi Nilai-Aktivitas dan Simbol-Simbol Islami di Madrasah, (El-Hikmah, Vol, 9, No,), 1 Juni 2015, 21-42. ISSN: 2086-3594. 
penuh untuk menanamkan pengetahuan dan menentukan teknik evaluasi yang tepat serta membuat instruksi budaya religius dalam bait-bait kalimat atau unit-unit/bab-bab modul, yang ini terasa lebih mudah, tanpa harus melibatkan warga sekolah untuk membangun pendidikan karakter (karakter religius) kepada peserta didik.

Penulis sadar memang, banyak faktor eksternal (lingkungan/keluarga) yang dapat membangun karakter peserta didik, dan tidak pula menafikan bahwa peranan lingkungan sangat mendukung dalam mengembangkan karakter khususnya karakter religius ini, akan tetapi seorang pengajar jangan berhenti di situ, seharusnya ia bertindak cepat dengan meramu/meracik/membuat modulnya sendiri yang multi manfaat (lengkap di dalamnya muatan kognitif, psikomotorik dan serat afektifnya) karena di sanalah tingkat kepuasan seorang pengajar ketika ia berhasil mendidikkan kognitif, psikomotorik dan terlebih-lebih afektif kepada peserta didik. Adapun saran penulis bagi pengajar PAI dengan modular system ketika menulis modul itu agar lebih maksimal dan berhasil, haruslah meminta masukan dari para pakar/ahli terkait desain buku hingga isi/materi/konten.

Penulis juga menyarankan guru $\mathrm{PAI}^{17}$ mampu mengembangkan desain sistem pembelajarannya sendiri, karena baru-baru ini kurikulum 2013 hampir merata diberlakukan sekolah-sekolah di Indonesia. Upaya pengembangan desain sistem pembelajaran itu dapat dilakukan dengan meminjam dan mengaplikasikan salah satu teori pengembangan desain pembelajaran yang telah banyak digagas para ahli. Usulan penulis, model Dick, Carey dan Carey dapat digunakan dalam merancang sistem pembelajaran dalam konteks kurikulum 2013. ${ }^{18}$ Ada beberapa tahap pengembangan model sistem pembelajaran Dick, Carey dan Carey yang terdiri dari sepuluh

17 Baca, Pengembangan metodologi pembelajaran Pendidikan Agama Islam (PAI) oleh: Muhaimin, Model Pengembangan Kurikulum \& Pembelajaran dalam Pendidikan Islam Kontemporer di Sekolah/Madrasah dan Perguruan Tinggi, (Malang: UIN-Maliki Press, 2016), hlm. 91-113.

${ }^{18}$ Baca, Yunus Abidin, Desain Sistem Pembelajaran dalam Konteks Kurikulum 2013, (Bandung: PT Refika Aditama), cet ke-2, hlm. 44-53. 
tahap, 1) Analisis kebutuhan untuk mengidentifikasi tujuan pembelajaran, 2) Melakukan analisis pembelajaran, 3) Menganalisis siswa dan konteks pembelajaran, 4) Merumuskan tujuan performasi, 5) Mengembangkan instrumen penilaian, 6) Mengembangkan strategi pembelajaran, 7) Mengembangkan materi pembelajaran, 8) Merancang dan mengembangkan evaluasi formatif, 9) Merevisi pembelajaran, 10) Mengembangkan evaluasi sumatif. Serta tidak kalah penting guru terus membuka diri (menelaah buku) atau kembali ke bangku kuliah (S2/S3) demi kematangan intelektual.

\section{Kesimpulan}

Perkembangan Instruksional Modular System di Sekolah Indonesia. Melihat sejarahnya, pada tahap pertama (ekspresimentasi) sistem pengajaran/pembelajaran baru ini diterapkan pada sekolah-sekolah yang dipergunakan sebagai Proyek Perintis Sekolah Pembangunan (PPSP). Seperti kita ketahui Departemen Pendidikan \& Kebudayaan telah menunjuk diselenggarakannya PPSP itu pada 8 (delapan) tempat yakni di Padang, Jakarta, Bandung, Semarang, Yogyakarta, Surabaya, Malang dan Ujungpandang. Masing-masing PPSP ditangani oleh IKIP Negeri setempat.

Sejak tahun 1975 sistem pembelajaran/pengajaran dengan modul ini dilaksanakan pada PPSP tersebut. Untuk kelas I, IV, VI, dan IX (kelas IX pada PPSP setingkat dengan kelas I SMA). Pada waktu itu belum seluruh bidang studi diajarkan dengan sistem modul, melainkan baru untuk bidang studi IPA, IPS, Matematika, dan Bahasa (Bahasa Indonesia dan Bahasa Inggris). Pada perkembangannya dewasa ini, modular system diberlakukan untuk pembelajaran pendidikan agama Islam (PAI).

Peranan Modular System dalam Pendidikan Agama Islam di Sekolah. pembelajaran PAI dengan modular system sangat efektif dan efisien. Sangat membantu gaya belajar, kebutuhan, dan motivasi tiap individu peserta didik serta dapat menghemat waktu dan biaya.

Implikasi Modular System Pendidikan Agama Islam untuk Mengembangkan Pendidikan Karakter Peserta Didik di Sekolah 
pembelajaran PAI dengan modular system membantu peserta didik dalam penguasaan materi dan diharapkan cakap dalam mempraktekkan pengetahuannya itu dalam ritual ibadah. Sebagai implikasi pembelajaran PAI dengan modular system bisa mengembangkan pendidikan karakter peserta didik bisa dianalisis dari tujuan modular system. Modular system yang berciri khas pembelajaran individual, mastery learning dan maju berkelanjutan penulis memiprediksikan akan mengembangkan karakter peserta didik, 1) Gemar memaca, 2) Rasa ingin tahu, 3) Jujur, 4) Disiplin, 5) Kerja keras, 6) Kreatif, 7) Mandiri, 8) Demokrasi, 9) Komonikatif, 10) Tanggungjawab, 11) Strategi belajar. Dan bagi pengajar yang mampu membuat modul sendiri dalam praktek modular system ini maka akan lebih memungkinkan untuk mengembangkan karakter peserta didik khususnya karakter religius. 


\section{DAFTAR REFERENSI}

Al-Qur'an in word, Q.S. Al-Alaq

Abidin, Yunus. Desain Sistem Pembelajaran dalam Konteks Kurikulum 2013, Bandung: PT Refika Aditama, cet ke2

B. Suryosubroto, Sistem Pengajaran dengan Modul, Yogyakarta: PT. Bina Aksara, 1983

Baharuddin \& Esa Nur Wahyuni, Teori Belajar dan Pembelajaran, Jogjakarta: Ar-Ruzz Media, 2007

Fitriani, Mohamad Iwan. Pola Pengembangan Program Suasana Religius Melalui Aktualisasi Nilai-Aktivitas dan Simbol-Simbol Islami di Madrasah, El-Hikmah, Vol, 9, No,, 1 Juni 2015, 21-42. ISSN: 2086-3594

Hamalik, Oemar, Sistem Pembelajaran Jarak Jauh dan Pembinaan Ketenagaan, Bandung: Trigenda Karya, 1994

Kementrian Pendidikan Nasional Badan Penelitian Dan Pengembangan Pusat Kurikulum, Pedoman Pelaksanaan Pendidikan Karakter Jakarta: Balitbang Diknas, 2010

Mularsih, Heni, Strategi Pembelajaran, Tipe Kepribadian dan Hasil Belajar Bahasa Indonesia Pada Siswa Sekolah Menengah Pertama, Jurnal, Makara, Sosial Humaniora, Vol. 14, No. 1, Juli 2010: 65-74

Muhaimin, Pemikiran Pendidikan Islam, Bandung: Trigenda Karya, 1993

Muhaimin, Model Pengembangan Kurikulum \& Pembelajaran dalam Pendidikan Islam Kontemporer di 
Sekolah/Madrasah dan Perguruan Tinggi, Malang: UIN-Maliki Press, 2016

Muhaimin. Paradigma Pendidikan Islam Upaya Mengefektifkan Pendidikan Agama Islam Di Sekolah.Bandung: Remaja Rosda Karya: 2001

Nana Sudjana \& Ahmad Rivai, Teknologi Pengajaran, Bandung, Sinar Baru, 1989

Nasution, S. Berbagai Pendekatan dalam Proses Belajarn \& Mengajar, (Jakarta: PT Bumi Aksara, 2006

R. M. Gagne \& L. J. Briggs, Principle of Instructional Design, 1nd ed New York: CBS College Publishing, 1979

Sastrawijaya, A. Tresna, Pengembangan Program Pengajaran, Jakarta: PT Rineka Cipta, 1991

Slameto, Proses Belajar Mengajar dalam Sistem Kredit Semester 'SKS', Jakarta: Bumi Aksara, 1991

Sri Anita W Dkk, Strategi Pembelajaran di SD, Tangerang Selatan: Universitas Terbuka, 2014

Suparman, M. Atwi, Desain Instruksional Modern, cet-4, Jakarta: Erlangga, 2014

Vebriarto, Pengantar Pengajaran Modul, Yogyakarta: Pendidikan Paramita, 1981

Wilis Dahar, Ratna Teori-teori Belajar \& Pembelajaran, Jakarta: Erlangga, 2011 